\title{
Authors' Instructions: Strategy to Improve The Potential of Aceh Regional Bureau of Logistic in Disaster Emergency Response As Support of Humanity Logistic Distribution in Aceh Using Swot and QSPM Analysis Methods
}

\author{
${ }^{1}$ Muhammad Nur Akmal, ${ }^{2}$ Muhammad Dirhamsyah, and ${ }^{3}$ Yusya Abubakar \\ Magister of Disaster Science, Syiah Kuala University, Banda Aceh, Indonesia ${ }^{1}$ \\ Engineering Department, Syiah Kuala University, Darussalam, Banda Aceh, Indonesia ${ }^{2}$ \\ Agricultural Product Technology Department, Syiah Kuala University Darussalam, Banda \\ Aceh, Indonesia ${ }^{3}$ \\ \{akmal_rev@yahoo.com¹,mdirhamsyah@unsyiah.ac.id²,yusya.abubakar@unsyiah.ac.id $\left.{ }^{3}\right\}$
}

\begin{abstract}
Logistic Bureau has one of many vital functions in supporting logistical distribution during a disaster emergency period, especially in disaster-prone countries such as Indonesia. This study was aimed to find out the roles and functions of Logistic Bureau in Aceh Regional as a supporter of humanitarian logistical distribution during the emergency response period and to develop alternative strategies to improve their roles and functions. This research was a descriptive study embracing qualitative and quantitative design. The data used in this study included primary data and secondary data. Samples were determined by the triangulation method. The research samples were Logistic Bureau of Aceh Regional, Aceh Provincial Social Service, Aceh Disaster Management Agency, and Headman of Dayah Timu Village, Pidie Jaya Regency. Data were collected by participatory observation, in-depth interviews, and documentation for the same data source simultaneously. These results then were analyzed descriptively based on the information in the study so they could be used to develop alternative strategies. The results of the research show that the Logistic Bureau of Aceh Regional only has the role and function as the logistics manager at the moment. Aceh Provincial Social Service, commanded by Aceh Disaster Management Agency, is the one that is responsible for distributing the logistics during the emergency response. People affected by the Pidie Jaya earthquake in 2016 reported that the logistics distribution system was unfair between one village and another so that the community hoped that the distribution system could be improved. Alternative strategies compiled based on the results of the SWOT and QSPM analysis are: Logistic Bureau of Aceh Regional should collaborate with other government agencies, make a program, utilize strong ties with the local government, and increase the efficiency of facilities in distributing logistics by using Government Rice Reserves which are owned and warehouses owned by the Logistics Bureau that are spread in several Aceh Districts. If this is carried out, it is expected that the logistics distribution can be quickly and precisely distributed to disaster victims.
\end{abstract}

Keywords: Strategy, Emergency Response, Potential Distribution, and Logistics. 


\section{Introduction}

Data National Disaster Management Agency [1] mentions that Indonesia is a natural disaster-prone country so that disaster can occur anywhere and anytime. Indonesians are familiar with the incidents of forest fires, droughts, landslides, hurricanes, floods, volcanic eruptions, earthquakes and tsunamis that have a detrimental effect both in terms of material and mental aspects.

The most potential disasters that hit Indonesia were earthquake and tsunami. During 2004 to 2011 , there have been at least five earthquakes followed by tsunamis in Indonesia including Aceh-Nias, Pengandaran, Bengkulu, Mentawai Islands, northern Papua Island, and Padang. The most devastating earthquake and tsunami that occurred in Aceh and Nias on December $26^{\text {th }}$, 2004 caused around 220,000 fatalities and more than 1 million people lost their homes [2].

Preparedness is an important component in preventing disaster risk. In preparedness, there are nine components of activities that need to be carried out: (1) risk assessment, (2) contingency planning, (3) resource mobilization, (4) training and education, (5) coordination, (6) response mechanism, (7) early warning, (8) information systems, and (9) drilling/simulation.

To ensure the achievement of preparedness, the focus of the program should be on the development of early warning systems, the increase of evacuation capacity, the maintenance of infrastructure facilities for disaster preparedness and simulation. In addition, preparedness to meet basic disaster relief needs is very important to be performed to prevent more casualties. Accurate and efficient information is needed in distributing the needs of disaster humanitarian aid materials. It aims to achieve the right targets in a timely manner so that the survivors do not experience suffering because of waiting for long life assistance.

The timely logistical distribution system is required by the community affected by the disaster. Processes and mechanisms are regulated based on PERKA BNPB No 2 (2012) [3] concerning logistical assistance in the state of emergency response. Management of logistical assistance in the state of an emergency is an integrated activity to manage disaster relief items. The integrated approach includes resource search, logistics procurement, quality assurance, packaging, transportation, warehouse storage, and logistics inventory management. The supply process activities, distribution to the community involve various stakeholders.

Public Company Logistics Agency (Perum Bulog) is a state-owned public company engaged in the food logistics field. Perum Bulog has a program called CBP (Government Rice Reserve) which aims to strengthen the pillars of food stability. CBP is needed to strengthen household food security in emergency situations, such as natural disasters (floods/droughts, pest/disease attacks, volcanic eruptions, earthquakes, tsunamis, etc.) and human-made disasters (social conflicts). To maximize logistical assistance is not enough with this CBP program only, but it also needs the location of logistics warehouses that are safe from disasters and other roles are needed to optimize logistical assistance during the disaster response period.

Kovacs, Tatham, \& Paul [4] mentions that logistics plays an important role in disaster management. Logistics provides services between disaster and preparedness, between providing and distributing humanitarian assistance and equipment, between National Board for Disaster Management (BNPB) and regional disaster management agency (BPBD), and logistics also plays an important role in determining the effectiveness and responsiveness in almost all humanitarian assistance programs, such as health, food, shelter, water, and sanitation. Caroline [5] note that serious efforts in coordination are carried out by humanitarian logistic agents continuously, which involve complex interactions and adaptations. If the modeling concept on humanitarian logistics can be properly simulated and applied, involves many humanitarian 
logistical supply chain actors, then the appropriate and effective policies can be taken against the problems commonly faced in supplying chain operations.

Ichsa [6] in his research on the management of distribution of logistical assistance for natural disasters victims (a flood disaster case study in Bojonegoro Regency) concluded that the victims of the Bengawan Solo river overflow were forced to beg from highway users in BojonegoroCepu because they had not received assistance from the Government, while the supply in the regional disaster management agency (BPBD) of Bojonegoro Regency was still sufficient. This happened because of the weak governance of the aid distribution during emergencies performed by the State Logistics Agency and other Government Offices. The importance of the aid management distribution demands coordination from various actors. The aid distribution mechanism must also meet the standard of operating procedures. In that research, the concern that has not been achieved is creating alternative strategies to improve the role and function of good logistics distribution so that assistance can be channeled appropriately to disaster victims.

\section{Research Methodology}

The type of this research was descriptive qualitative research embracing in-depth interview techniques to obtain data through perspective with strategies that are interactive and flexible. Data-sources of this study consisted of primary data (field research) and secondary data (library research). The primary data were obtained through participant observation (in-depth observation) and in-depth interviews, while secondary data were gathered by collecting social-related research references and other supporting data.

This research was conducted at the Logistic Bureau of Aceh Regional, Aceh Provincial Social Service, Aceh Disaster Management Agency, and Dayah Timu Village, Pidie Jaya Regency. The determination of the Logistic Bureau of Aceh Regional as the research location was based on the consideration that this institution has the potency to become a supporting center for humanitarian logistical distribution in Banda Aceh. The selection of Aceh Provincial Social Service and Aceh Disaster Management Agency was based on the consideration that Aceh Disaster Management Agency was the logistics distribution command center during the disaster emergency period and the Aceh Provincial Social Service is the Department that cooperates with the Logistics Bureau to distribute rice both during disasters and other community assistance. The study also examined the beneficiary communities represented by Headman of Dayah Timu Village, with the aim to find out community satisfaction with the assistance provided by the Government during the 2016 Pidie Jaya earthquake emergency.

Samples were determined by using the triangulation method. The samples in this study were 4 people: section chief of the Logistic Bureau of Aceh Regional, the head of Prevention and Preparedness section of the Aceh Disaster Management Agency, the head of the Natural Disaster Social Protection section of the Aceh Provincial Social Service, and the Headman of Dayah Timu Village, Pidie Jaya Regency.

The data were analyzed by descriptive qualitative and quantitative methods, using a SWOT analysis (Strengths, Weaknesses, Opportunities, Threats) and QSPM (Qualitative Strategic Planning Matrix) analysis to design alternative strategies in order to optimize the potential of Logistic Bureau as a logistics distribution center in the emergency response disaster.

\section{Discussion}

The amount of rice available at Logistic Bureau of Aceh Regional greatly influences the process of rice distribution to the people of Aceh. Rice supplies managed by the Logistic Bureau 
of Aceh Regional are intended to anticipate uncertainty in demand and maintain the possibility of crop failure. When a disaster strikes, the Logistic Bureau of Aceh Regional do not participate directly at the location of the accident, but they only provide Government Rice Reserve (CBP) owned through the Social Service which is commanded by the Aceh Disaster Management Agency (BPBA) as requested by the Government. CBP is distributed by the Aceh Provincial Social Service by the requests from the Government with a process of an administrative system controlled by the Aceh Government.

\subsection{The Role of Logistic Bureau of Aceh Regional in Logistics Distribution during Disaster Emergency Response}

The amount of rice available at Logistic Bureau of Aceh Regional greatly influences the process of rice distribution to the people of Aceh. Rice supplies managed by the Logistic Bureau of Aceh Regional are intended to anticipate uncertainty in demand and maintain the possibility of crop failure. When a disaster strikes, the Logistic Bureau of Aceh Regional do not participate directly at the location of the accident, but they only provide Government Rice Reserve (CBP) owned through the Social Service which is commanded by the Aceh Disaster Management Agency (BPBA) as requested by the Government. CBP is distributed by the Aceh Provincial Social Service by the requests from the Government with a process of an administrative system controlled by the Aceh Government.

The Logistic Bureau of Aceh Regional does not have specific staff with backgrounds and experts in the field of disaster, and there is no organizational structure to distribute humanitarian logistical assistance. Logistic Bureau of Aceh Regional had never conducted training for employees related to disaster mitigation and logistics distribution during the disaster emergency response period. The warehouse facilities were not used as a logistics warehouses during the emergency response period. The warehouses were only used as needed if they are requested directly by the governor to the Logistics Bureau. During the earthquake emergency response in Pidie Jaya in 2016, the Governor wrote to the National Logistics Agency in attempt to request a logistics warehouse of Logistic Bureau the Pidie Jaya Regional located in Dayah Timu Village to be used as a public kitchen instead of as a humanitarian logistical center.

The Logistic Bureau has 100 tons Government Rice Reserve (CBP) for the district and 200 tons for the province. During the emergency response, CBP can only be issued on the condition that there must be a state of disaster emergency by the government and it should be requested directly from the regent where the disaster occurred with the approval from the governor.

The community response represented by the village head of one of the villages affected by the Pidie Jaya earthquake in 2016 stated that the logistics distribution system at that time was not distributed equitably. Many villages did not receive assistance in a timely manner and the type of assistance was only in the form of patch-up food such as noodle, little rice, and other basic necessities, even though the logistic bureau's warehouse was located in the village.

\subsection{Alternatives Strategy}

From the results of the research that has been gathered, starting from knowing the role of Logistics Bureau of Aceh Regional as a support of logistical distribution during the emergency response period to knowing the response of the Pidie Jaya community, as well as from previous research [6]-[9], it can be concluded that there are internal and external potential factors of Bulog Corporation through IFAS and EFAS matrix 
Table 1. Internal Factor Analysis Summary (IFAS)

\begin{tabular}{|c|c|c|c|}
\hline Internal Factors & Quality & Rating value & Weighted value \\
\hline \multicolumn{4}{|l|}{ STRENGTHS } \\
\hline $\begin{array}{l}\text { The logistic bureau has government } \\
\text { rice reserves of up to } 200 \text { tons per } \\
\text { year }\end{array}$ & 0,17 & 4 & 0,68 \\
\hline $\begin{array}{l}\text { The logistic bureau has a warehouse } \\
\text { with a large logistical capacity }\end{array}$ & 0,16 & 4 & 0,64 \\
\hline $\begin{array}{l}\text { The logistic bureau has a large } \\
\text { number of supporting staffs } \\
\text { throughout Aceh }\end{array}$ & 0,08 & 2 & 0,16 \\
\hline $\begin{array}{l}\text { The logistic bureau has strong ties } \\
\text { with the Government }\end{array}$ & 0,07 & 2 & 0,14 \\
\hline $\begin{array}{l}\text { Logistics quality check is performed } \\
\text { before and after distribution }\end{array}$ & 0,07 & 2 & 0,14 \\
\hline SUB TOTAL & 0,55 & & 1,76 \\
\hline \multicolumn{4}{|l|}{ WEAKNESSES } \\
\hline $\begin{array}{l}\text { The logistic bureau does not have a } \\
\text { specific staff or organizational } \\
\text { structures in emergency response } \\
\text { logistics distribution }\end{array}$ & 0,10 & 2 & 0,2 \\
\hline $\begin{array}{l}\text { The logistic bureau has never been } \\
\text { involved directly in logistics } \\
\text { distribution during the disaster } \\
\text { emergency period }\end{array}$ & 0,13 & 3 & 0,39 \\
\hline $\begin{array}{l}\text { The logistic bureau does not have an } \\
\text { SOP as a logistics distributor during } \\
\text { the disaster emergency period }\end{array}$ & 0,11 & 3 & 0,33 \\
\hline $\begin{array}{l}\text { The logistic bureau does not } \\
\text { cooperate beside with other agreed } \\
\text { partners or government agencies }\end{array}$ & 0,11 & 3 & 0,33 \\
\hline SUB TOTAL & 0,45 & & 1,25 \\
\hline TOTAL & 1,00 & & 3,01 \\
\hline
\end{tabular}

Source: primary data (modified), 2018

\subsection{Subtitle}

From Table 1 above, it can be seen that the maximum possible value is four, which means maximum strength and the lowest value is zero, which means full weakness. The value above 3.0 is included in the high category, values around 2.0 to 2.99 are categorized as a medium, while values between 1 and 1.99 are categorized as low. Then, the 3.01 weighted value is included in the high category. Furthermore, the External Factor Analysis (EFAS) can be seen in Table 2 below.

Tabel 2. External Factor Analysis Summary (EFAS)

\begin{tabular}{llll} 
External Factors & Quality & Rating value & Weighted value \\
\hline Opportunities & & & \\
\hline $\begin{array}{l}\text { Logistic bureau has 15 logistics } \\
\text { warehouses spread across 8 Aceh }\end{array}$ & 0,16 & 4 & 0,64 \\
Districts
\end{tabular}




\begin{tabular}{lccc}
$\begin{array}{l}\text { The logistic bureau has a supporting } \\
\text { facility for distributing logistics from } \\
\text { small to large-sized cars }\end{array}$ & 0,12 & 3 & 0,36 \\
\hline $\begin{array}{l}\text { Periodic socialization to villages in } \\
\text { distributing affordable rice }\end{array}$ & 0,08 & 2 & 0,16 \\
\hline$\quad$ SUB TOTAL & $\mathbf{0 , 4 8}$ & $\mathbf{1 , 5 2}$ \\
\hline$\quad$ Threats & 0,16 & 3 & 0,48 \\
\hline $\begin{array}{l}\text { Lack of coordination between the } \\
\text { logistic bureau and related agencies in } \\
\text { terms of logistics distribution }\end{array}$ & 0,14 & 3 & 0,42 \\
\hline $\begin{array}{l}\text { The logistic bureau has not yet } \\
\text { developed, only focusing on rice } \\
\text { distribution with a program like } \\
\text { affordable rice }\end{array}$ & & & $\mathbf{1 , 2 8}$ \\
\hline \multicolumn{1}{c}{ SUB TOTAL } & $\mathbf{0 , 4 2}$ & $\mathbf{2 , 8 1}$
\end{tabular}

Source: primary data (modified), 2018

From Table 2, it can be seen that the weighted value figure is 2.81 with the assumption that the potential of the Logistics Bureau in supporting logistic distribution during the disaster emergency period is strongly supported by the facilities currently owned. The value of 2.81 belongs to a medium category, which means that the Bulog Corporation has the opportunity in supporting facilities to support logistics distribution such as logistics warehouses that are spread across several regions of Aceh with a large holding capacity.

The threat in the form of lack of coordination and collaboration with other agencies in the distribution of logistical assistance during disaster emergency response has a lower value than the opportunity so that opportunities for development are greater.

The average value of IFE is 3.01 and the average value of the EFE is 2.81 so the total weighted value is 2.91 . The meeting point of the two values is in quadrant II which can be seen in Table 3 below

Table 3. Matrix Internal-External (IE)

\begin{tabular}{|c|c|c|c|}
\hline & $\begin{array}{l}\text { Strong } \\
\mathbf{3 , 0 - 4 , 0} \\
\end{array}$ & $\begin{array}{l}\text { Midd } \\
\text { 2-2,99 }\end{array}$ & $\begin{array}{l}\text { Weak } \\
1-1,99 \\
\end{array}$ \\
\hline $\begin{array}{l}\text { Strong } \\
3,0-4,0 .\end{array}$ & $\begin{array}{c}\text { I } \\
\text { Growth.... } \\
\text { strategy }\end{array}$ & $\begin{array}{l}\text { II } \\
\text { Growth........ } \\
\text { strategy }\end{array}$ & $\begin{array}{l}\quad \text { III } \\
\text { Contraction } \\
\text { strategy }\end{array}$ \\
\hline $\begin{array}{c}\text { Middle } \\
2-2,99\end{array}$ & $\begin{array}{c}\text { IV } \\
\text { Stability } \\
\text { strategy }\end{array}$ & $\begin{array}{c}\mathbf{V} \\
\text { Stability } \\
\text { strategy }\end{array}$ & $\begin{array}{l}\quad \text { VI } \\
\text { Contraction } \\
\text { strategy }\end{array}$ \\
\hline $\begin{array}{l}\text { Weak } \\
1-1,99\end{array}$ & $\begin{array}{r}\text { VII } \\
\text { Growth } \\
\text { strategy }\end{array}$ & $\begin{array}{l}\text { VIII } \\
\text { Growth } \\
\text { strategy }\end{array}$ & \begin{tabular}{l}
\multicolumn{1}{c}{$\mathbf{I X}$} \\
Contraction \\
strategy
\end{tabular} \\
\hline
\end{tabular}

Source: primary data (modified), 2018 
From Table 3 above, it can be seen that the meeting points of the two axes are in the cell or the second quadrant which shows the strategy needed to strengthen the potential of Logistic bureau as a supporter of logistics distribution during the emergency response strategy is growth.

By determining the right weight and strategy, it is found that there are five key strategies to strengthen the potential of the logistic bureau as a logistics distribution distributor during the emergency response period through the stages in the SWOT analysis which can be seen in table 4 below.

Tabel 4. SWOT Matrix

\begin{tabular}{|c|c|c|c|}
\hline $\begin{array}{c}\text { Strategi } \\
\text { S-O }\end{array}$ & Strategi W-O & $\begin{array}{c}\text { Strategi } \\
\text { S-T }\end{array}$ & $\begin{array}{c}\text { Strategi } \\
\text { W-T }\end{array}$ \\
\hline $\begin{array}{l}\text { 1.Logistic bureau } \\
\text { created a program } \\
\text { by cooperating } \\
\text { with the } \\
\text { Government } \\
\text { Agency in utilizing } \\
\text { the facilities } \\
\text { owned. } \\
\text { Utilizing a periodic } \\
\text { quality check } \\
\text { logistics program at } \\
\text { CBP to arrange } \\
\text { preparations in } \\
\text { advance if a threat } \\
\text { occurs. }\end{array}$ & $\begin{array}{l}\text { 1.Logistics Bureau } \\
\text { makes a program } \\
\text { for logistics } \\
\text { distribution } \\
\text { during the } \\
\text { disaster } \\
\text { emergency period } \\
\text { by utilizing the } \\
\text { workforce it had. }\end{array}$ & $\begin{array}{l}\text { 1. Utilizing the } \\
\text { Government network } \\
\text { for logistics } \\
\text { distribution during the } \\
\text { emergency response } \\
\text { period and responding } \\
\text { to requests for } \\
\text { assistance from the } \\
\text { Office relating to } \\
\text { submitting to the } \\
\text { Government. }\end{array}$ & $\begin{array}{l}\text { 1. Creating an } \\
\text { organizational structure } \\
\text { for the emergency } \\
\text { response period in } \\
\text { logistics distribution } \\
\text { and cooperating with } \\
\text { partners by utilizing } \\
\text { Government access. }\end{array}$ \\
\hline
\end{tabular}

After getting a reinforcement strategy to increase the role and function of the Regional Division of Logistics Bureau as a supporter of logistical distribution during the disaster emergency period, it is crucial to to get the most important strategy from the five strategies using QSPM analysis with the stages of determining weight and Attractiveness scores (US) by discussing with one expert respondent from logistic bureau and calculating Total Attractiveness scores (TAS). To be clearer, the sequence of strategies needed to improve the role and function of the logistic bureau of Aceh Regional Division as a supporter of logistics distribution during the disaster emergency response period can be seen in the alternative strategy table $\mathbf{5}$ using QSPM analysis as follows.

Table 5. Strategic alternatives by QSPM method

\begin{tabular}{lcccc} 
Strategic alternatives & Quality & AS & TAS & Rate \\
\hline $\begin{array}{l}\text { 1. Create a cooperation } \\
\text { program with the }\end{array}$ & & & & \\
$\begin{array}{l}\text { Government Office by } \\
\text { utilizing the facilities } \\
\text { owned }\end{array}$ & 0,20 & 3,8 & 0,76 & 1 \\
\hline $\begin{array}{l}\text { 2. Create a cooperation } \\
\text { program with the Government }\end{array}$ & 0,20 & 3,1 & 0,62 & 3 \\
$\begin{array}{l}\text { Office by utilizing the } \\
\text { facilities owned }\end{array}$ & & & &
\end{tabular}


3. Create a program for logistics distribution by utilizing the workforce owned.

4. Utilizing the

Government network for logistics distribution during the emergency response period and responding to requests for assistance from 0,20 2,7 0,54 5 related Offices, Institutions, and the Business World by submitting to Government.

5. Create an organizational structure for emergency response periods in logistics distribution and establish partnerships with partners by utilizing government access.

TOTAL 1,0

Table 5 shows strategies needed to strengthen the role and function of the Logistics Bureau of Aceh Regional Division as a supporter of logistical distribution during the disaster emergency response period. Alternative strategies with the highest value are the strategies that need to be implemented first. The results of the QSPM analysis show five alternative strategies

Based on the results of the SWOT analysis and QSPM, the alternative strategies were obtained to improve the role and function of the Bureau of Logistics as support for logistics distribution.

a. The main alternative strategy is to create a cooperation program with other government agencies (TAS Value 0.76 ) by utilizing the facilities owned by the Bureau of Logistics in the distribution of logistical assistance, by utilizing CBP owned up to 200 tons per year and by spreading Bulog Perum warehouses in several districts of Aceh Province.

b. Utilizing the Government network (TAS Value 0.72) for logistical distribution of the emergency response period and responding to requests for assistance from related agencies, non-governmental institutions, and the business world by submitting to the government.

c. Utilizing a logistic quality checking program to anticipate an earlier threat (TAS Value 0.62).

d. Creating an organizational structure for emergency response periods in logistics distribution and collaborating with partners by utilizing government access (TAS Value 0.58)

e. Making a program for logistics distribution by utilizing the workforce that is owned (TAS Value 0.54).

The strategy chosen is only one with the highest TAS value of 0.76: Aceh regional Logistic bureau establishing cooperation with government agencies by utilizing strong ties with the local Government and facilities in distribution logistics, by utilizing CBP up to 200 tons per year as 
well as by spreading warehouses owned by Public Logistics Agency in several Aceh Districts. Respondent experts have an interest in these alternative strategies because they consider that by cooperating with the Government Service and other institutions with agreements known by the central government and utilizing the maximum CBP by the logistic bureau, the distribution of humanitarian logistics during the emergency response period disasters will be more precise and quick to the disaster victims.

The results of previous research conducted by Reza [10] revealed that the organizational structure of the National Logistics Agency is very formal and they already have a clear division of their respective work tasks which are not too complex. The type of work within the logistic bureau is not too much division, so it will not cause more organizational problems. And of course, it becomes a supporting factor. However, the organizational structure of Bulog is also centralistic in nature, as a consequence, it can be an obstacle and result in slowing down the State Logistics Agency in following up on various problems, also Bulog Corporation does not have work bond with the Government Service other than Social Affairs in distributing humanitarian logistics distribution in the event of a disaster.

\section{Conclusions}

From the research results and discussion, the following conclusions can be taken.

1. Based on the role of the logistic bureau of Aceh regional, the cooperation only has a role as CBP manager so that the quality should be maintained when it is distributing to disaster victims. The Social Service has the role to distribute CBP to disaster victims during the disaster response period. Aceh Disaster Management Agency (BPBA) gets a role as a commander. The Logistics Bureau facilities are only utilized in emergency situations, such as the logistic bureau warehouse which could be used for public kitchens in the Pidie Jaya earthquake case in 2016. From the interviews with Pidie Jaya 2016 earthquake victims, the Government and other Institutions, logistics were still not distributed equitably.

2. From SWOT analysis and QSPM method, alternative strategies were obtained to improve the role and function of the logistic bureau as supporting logistics distribution and the main alternative strategy with the highest TAS value of 0.76 is to conduct a collaborate program with other Government Offices by utilizing strong relationship with the local government.

\section{REFERENCES}

[1] Bakornas, Pedoman penanggulangan banjir tahun 2007-2008. Jakarta, 2007.

[2] TDMRC, "Studi pengurangan risiko bencana dan kesiapsiagaan masyarakat," Banda Aceh, 2011.

[3] Peraturan Kepala Badan Penanggulangan Bencana Nomor 3, Pedoman Umum Pengkajian Risiko Bencana. 2012.

[4] G. Kovacs, P. Tatham, and D. L. Paul, "What skills are needed to be a humanitarian logistician?,” J. Bus. Logist., vol. 33, no. 3, pp. 245-258, 2012.

[5] K. C. Caroline, "Hybrid simulation modeling for humanitarian relief chain coordination," J. Humanit. Logist. Supply Chain Manag., vol. 5, no. 3, pp. 325 - 347, 2015.

[6] M. Ichsa, "Tata kelola distribusi logistik korban bencana alam," urnal Adm. Publik, vol. 3, no. 5, pp. 812-817, 2015.

[7] A. R. Nahry and H. Burhan, "Analisis karakteristik perjalanan primer truk angkutan barang di jakarta: Studi kasus terminal angkutan barang pulo gebang dan tanah merdeka," J. Tek. Sipil dan Perenc., vol. 17, no. 2, 2013. 
[8] M. H. R. Kasih, I. N. Pujawan, and A. Rahman, "Model penempatan pusat distribusi logistik perkotaan untuk modern retailers degan pertimbangan integrasi intermodal untuk kota Surabaya," Surabaya, 2009.

[9] S. W. Latifah, "Analisis faktor-faktor yang mempengaruhi rantai pasokan UMKM berbasis apel di Malang," 2017.

[10] I. Reza, "Studi deskriptif tentang kinerja perum bulog dalam pengadaan dan penyaluran beras untuk mendukung stabilisasi pangan," Kebijak. dan Manaj. Publik, vol. 5, no. 1, 2017. 